\title{
Two Compatibility Groups among ColI Plasmids
}

\author{
By SHEILA HOWARTH-THOMPSON, \\ HELEN M. HEFFERNAN AND MAUREEN D. BUCHAN \\ Department of Microbiology, Medical School, University of Otago, \\ Dunedin, New Zealand
}

(Received I8 October I973)

INTRODUCTION

Several investigations have shown that $\mathrm{fi}^{-} \mathrm{R}$ factors fall into a number of compatibility groups (summarized by Datta \& Hedges, 1973). Also Grindley, Grindley \& Anderson ( 1972) and Hedges \& Datta (1973) have described compatibility between certain pairs of R factors that determine I pili. Since Stocker (I966) first reported that the presence of the colicin I plasmid ColIb-P9 in bacteria prevented them accepting ColIa-CA53 it has generally been assumed that ColI plasmids are incompatible. We therefore wish to report that our investigation of a collection of wild coll plasmids shows that some are compatible and that they can be grouped on this basis.

In compatibility occurs between plasmids which are isogenic or closely similar and their inability to coexist in the same organism is explained on the basis of the maintenance site model; that is, by proposing that they have the same attachment site specificity and compete for a single maintenance site. Compatible plasmids, on the other hand, would have different specificities and would be matched to different maintenance sites (Novick, 1969). Incompatible plasmids are therefore inferred to be more closely related genetically than compatible ones.

With the exception of the now well-known ColIb-P9 (Ozeki, Stocker \& Smith, 1962), the other 24 Coll plasmids came from wild strains of Salmonella typhimurium and Escherichia coli. They have been described elsewhere with respect to their u.v.-protective effect and transferability (Howarth-Thompson, 1966; Howarth-Thompson, Meikle \& Cave, I97I). Coexistence, or compatibility, has been tested only between Ia and Ib pairs and the outcome of superinfection inferred from the type, or types, of I-colicin produced by the progeny; that is, Ia or Ib, or both Ia and Ib. The superinfection procedure was simplified by the use of transfer derepressed (Drd) mutants of the superinfecting plasmids.

\section{METHODS}

Coll plasmids. Collb-P9 came originally from Shigella sonnei P9 (Ozeki et al. 1962). The wild colicinogenic strains in which the other plasmids originated came from the Enteric Reference Laboratory, Colindale. The strains were kindly provided by Professor B. A. D. Stocker after being screened for the production of colicins of the Ia or Ib type (Stocker, I 966) and we transferred their ColI plasmids to laboratory strains for further investigations. Colindale reference numbers are used to identify them.

Evidence that they determine pili of the I-type is very good for two, Ia-Ni 2 and Ib-I Mi 420 , since we have obtained Drd mutants which confer on the host bacteria conspicuous sensitivity to the I sex phage Ifl (Lawn, Meynell, Meynell \& Datta, 1967). HFCT cultures 
(Stocker, Smith \& Ozeki, 1963) of the other 22 show a small degree of sensitivity but the results are less conclusive (Howarth-Thompson, unpublished). Their $\mathrm{fi}^{+}$or $\mathrm{fi}^{-}$status is unknown. Screening with low concentrations of tetracycline, chloramphenicol, streptomycin, kanamycin and ampicillin showed none carried resistance determinants (M. D. Cooke, personal communication).

Bacteria. Mutants of Salmonella typhimurium LT2, cysD 36 and ath-5 str-r, came originally from the Cold Spring Harbor collection and are maintained in this laboratory. Escherichia coli $\mathrm{K} 12$ strains $\mathrm{w}_{3} 1 \mathrm{IO}$ thy and $\mathrm{CR} 34$ thr leu thy lac str-s $\mathrm{F}^{-}$were kindly provided by Dr M. G. Smith and Dr D. Lane respectively. E. coli KI2-Row (CLI42), and indicator strains CL232 (which is sensitive to Ia colicin but immune to Ib) and CL223 (which is sensitive to Ib and immune to Ia) came from Professor B. A. D. Stocker.

Phage. Stock Ifl was obtained from Dr M. D. Cooke and was propagated on S. typhimurium LT2 M533, provided by Dr G. G. Meynell.

Superinfection procedure. All transfers were intraspecific with respect to the donor and recipient strains. Donor and recipient cultures were grown overnight in loosely capped $25 \mathrm{ml}$ bottles holding Io $\mathrm{ml}$ Difco brain-heart infusion broth (BH-broth), incubated without aeration or shaking. E. coli KI 2 and $S$. typhimurium LT2 grown in this way had viable counts of about $6.5 \times 10^{8}$ and $\mathrm{I} \cdot 5 \times 10^{9}$ bacteria/ml respectively. A growing culture of the donor strain was prepared by subculturing $0 . \mathrm{I} \mathrm{ml}$ of the overnight culture into $\mathrm{IO} \mathrm{ml}$ of fresh $\mathrm{BH}$-broth and growing without shaking until it contained about $10^{8}$ bacteria $/ \mathrm{ml}$, as determined by viable counts on BH-agar (Difco). The culture was then blended on an MSE homogenizer at full speed for I min, to break up clumps of bacteria, and $2.0 \mathrm{ml}$ was immediately mixed with $2.0 \mathrm{ml}$ of the overnight recipient culture at $37^{\circ} \mathrm{C}$. The mixture was slowly rotated on an inclined turntable for $15 \mathrm{~min}$ at $37{ }^{\circ} \mathrm{C}$, blended again for $2 \mathrm{~min}$, then immediately diluted and plated by the sandwich plate technique (Ozeki et al. 1962). The donor was contraselected by using $\mathrm{BH}$-agar containing streptomycin $(1000 \mu \mathrm{g} / \mathrm{ml})$. After incubation for $60 \mathrm{~h}$ the plates were overlayered with soft agar inoculated with the appropriate indicator bacteria. Inhibition zones in the indicator lawn showed up those recipient colonies which had received the donor plasmid. Approximately $\mathrm{I} \cdot 7 \times 10^{4}$ recipient colonies were screened in each experiment and transfer frequencies were calculated as the percentage of donor bacteria which had succeeded in transferring a plasmid to a recipient. Five of these colonies, inferred from their I-colicin type to have received the donor plasmid, were sampled by stabbing through the overlay, then resuspended in liquid medium and streaked on BH-agar. From each of the five streaks, five progeny colonies were tested for the production of colicins Ia or Ib, or both, using replica stab-plates and indicator strain CL232 or CL223. The process of streaking and stabbing was repeated two or three times, in series, with clones that were doubly colicinogenic, to establish whether or not they were stable.

\section{RESULTS AND DISCUSSION}

In the first series of transfers (Table I) Ia-Nı2drd-I was transferred to colicinogenic strains each carrying one of the eighteen wild-type (w.t.) Ib plasmids. We have used only strains already in our stocks so there has been very little repetition of tests of pairwise combinations in both $S$. typhimurium and E. coli, except for Ia-NI $2 d r d-I$ with Ib-I M I 420 or Ib-IMI240. Since their behaviour was substantially the same in both species the results presented in Table $I$ are discussed as a whole.

Taking stable coexistence as the criterion of compatibility it appears that Ib-I MI I 68 and Ib-I M I 420 fall into a different compatibility group, which we designate group 2, from the 
Table I. A derepressed ColIa plasmid, Ia-NI $2 d r d-I$, transferred to strains colicinogenic for various wild-type Collb plasmids

\begin{tabular}{|c|c|c|c|c|}
\hline \multirow[b]{2}{*}{$\begin{array}{l}\text { Ib w.t. plasmid } \\
\text { of recipient }\end{array}$} & \multirow[b]{2}{*}{$\begin{array}{c}\text { Ia transfer } \\
\text { frequency } \\
\text { (\% of donor) }\end{array}$} & \multicolumn{2}{|c|}{$\begin{array}{l}\text { Inferred colicinogenic types in } \\
\text { superinfected recipient colonies* }\end{array}$} & \multirow{2}{*}{$\begin{array}{l}\text { Predominant } \\
\text { plasmid } \\
\text { in singly } \\
\text { colicinogenic } \\
\text { progeny }\end{array}$} \\
\hline & & $\begin{array}{l}\text { Doubly } \\
\text { colicinogenic } \\
\text { (Ia; lb) }\end{array}$ & $\begin{array}{l}\text { Singly } \\
\text { colicinogenic }\end{array}$ & \\
\hline \multicolumn{5}{|c|}{ S. typhimurium LT2 $\times S$. typhimurium LT2 } \\
\hline $\begin{array}{l}\text { I M I I } 68 \\
\text { I M I420 } \\
\text { 2M384 I } \\
\text { I M646 } \\
\text { 2 M607 } \\
\text { I M I679 } \\
\text { I M304 } \\
\text { I MI240 } \\
\text { 2MI905 } \\
\text { 2M3070 }\end{array}$ & $\begin{array}{r}58.00 \\
104.00 \\
1.90 \\
52.00 \\
36.20 \\
30.70 \\
36.60 \\
28.00 \\
11.10 \\
0.08\end{array}$ & $\begin{array}{l}\text { Stable } \\
\text { Stable } \\
\text { Unstable } \\
\text { Unstable } \\
\text { Unstable } \\
\text { Unstable } \\
\text { N.D. } \\
\text { N.D. } \\
\text { N.D. } \\
\text { N.D. }\end{array}$ & $\begin{array}{l}\text { Ib } \\
\mathrm{Ia} \text { or } \mathrm{Ib} \\
\mathrm{Ia} \text { or } \mathrm{Ib} \\
\mathrm{Ia} \text { or } \mathrm{Ib} \\
\mathrm{Ia} \text { or } \mathrm{Ib} \\
\mathrm{Ia} \text { or } \mathrm{Ib} \\
\mathrm{Ia} \text { or } \mathrm{Ib} \\
\mathrm{Ib} \\
\mathrm{Ib}\end{array}$ & $\begin{array}{l}\text { N.A. } \\
\text { N.A. } \\
\text { Ib } \\
\text { Ib } \\
\text { Ib } \\
\text { Ib } \\
\text { Ib } \\
\text { Ib } \\
\text { Ib } \\
\text { Ib }\end{array}$ \\
\hline \multicolumn{5}{|c|}{$E$. coli w3IIo $\times E$. coli KI 2-Row } \\
\hline $\begin{array}{l}\text { I MI } 420 \dagger \\
\text { 2M2035 } \\
\text { 2M2373 } \\
\text { I M I I } 40 \\
\text { I MI } 843 \\
\text { P9 } \\
\text { 2M59 } \\
\text { I MI } 240 \\
\text { I M I } 992 \\
\text { I M I } 995\end{array}$ & $\begin{array}{r}16 \cdot 00 \\
12 \cdot 90 \\
8 \cdot 60 \\
10 \cdot 30 \\
43 \cdot 00 \\
31 \cdot 00 \\
51 \cdot 00 \\
16 \cdot 00 \\
6 \cdot 70 \\
6.90\end{array}$ & $\begin{array}{l}\text { Stable } \\
\text { Unstable } \\
\text { Unstable } \\
\text { Unstable } \\
\text { Unstable } \\
\text { N.D. } \\
\text { N.D. } \\
\text { N.D. } \\
\text { N.D. } \\
\text { N.D. }\end{array}$ & $\begin{array}{l}\mathrm{Ia} \\
\mathrm{Ia} \text { or } \mathrm{Ib} \\
\mathrm{Ia} \text { or } \mathrm{Ib} \\
\mathrm{Ia} \text { or } \mathrm{Ib} \\
\mathrm{Ia} \text { or } \mathrm{Ib} \\
\mathrm{Ib} \\
\mathrm{Ib} \\
\mathrm{Ia} \text { or } \mathrm{Ib} \\
\mathrm{Ia} \text { or } \mathrm{Ib} \\
\mathrm{Ia}\end{array}$ & $\begin{array}{l}\text { N.A. } \\
\text { Either } \\
\text { Ia } \\
\text { Ib } \\
\text { lb } \\
\text { Ib } \\
\text { Ib } \\
\text { Ib } \\
\mathrm{Ia} \\
\text { Ia }\end{array}$ \\
\hline
\end{tabular}

N.D., not detected; N.A., not applicable.

* All superinfected recipient colonies were initially detected by production of the donor colicin, Ia. However, when sampled, some yielded only Ib progeny, implying that Ia producers constituted only a minority of the colony population.

$\dagger$ Singly colicinogenic progeny rarely occur.

other sixteen Ib plasmids and Ia-NI 2 itself (group I). The latter group may be further classified by their interactions with Ni2 $d r d-I$, according to whether there is either unstable coexistence or no detectable coexistence. Unstable coexistence means that doubly colicinogenic progeny persisted through two or three rounds of restreaking of such clones but that each time singly colicinogenic progeny appeared. There was, however, variation in the degree of instability, e.g. in the case of Ib-I M2035, Ib-I M2373 and Ib-2M384I doubly colicinogenic progeny were usually in the majority, whereas for the rest of the plasmids in this category doubly colicinogenic progeny were in the minority. In Table I they have been arranged in descending order of stability. Even further classification on the basis of which of the two plasmids appeared most frequently in the singly colicinogenic progeny may be possible although, in general, it seemed to be the resident one (Table I). However, the fact that one of the plasmids is w.t. and the other a Drd mutant may have influenced this outcome since a bacterium carrying a Drd mutant will be at a slight growth disadvantage compared with one carrying a w.t. plasmid. This was first reported by Dowman \& Meynell (1970) and has also been observed by us. Nevertheless this growth disparity cannot always be effective, judging from the success of Ia-NI $2 d r d-I$ following superinfection of strains carrying w.t. Ib-I Mi 992 or Ib-I Mig95. 
The reasons for the quite wide variation in transfer frequency to the various recipients is unknown. It seems unrelated to the outcome of the superinfection, i.e. whether there was coexistence or not. In general they were somewhat lower than the frequencies to noncolicinogenic recipients which were about $150 \%$ for S. typhimurium and about $30 \%$ for E. coli.

We also tested the group 2 Ib plasmid I M 1420 in S. typhimurium crosses with recipients each carrying a w.t. Ia plasmid, the group I plasmid $\mathrm{N}_{12}$ or one of three others not yet allocated: K29, IM2037 or M6825. All showed stable coexistence with Ib-I M I 420drd-2, indicating that they belong to compatibility group $\mathrm{I}$. These results also demonstrated that Ia-NI 2 and Ib-IMI 420 coexist irrespective of which of them is Drd and which is w.t. In the case of this particular pair coexistence of the two w.t. plasmids was subsequently tested for and confirmed. Further support for this grouping was obtained by using the same four recipients and superinfecting with group I Ib-P9drd-I. No coexistence was found.

Finally, three additional Ia plasmids, Ni60, N 44 and 2 M70, were tested for coexistence with the group I Ib-Pydrd-I in E. coli. One, Ni60, showed unstable coexistence and the other two showed none. All three have therefore been put in group I.

The constitution of the two groups is as follows: group I comprises Ia plasmids, Ni2, K29, I M2037, M6825, Ni4, 2 M70 [Ni60] and presumably CA53 (Stocker, I 966), and Ib plasmids I M304, I Mi240, I Mi 905，2M3070，P9，2M59, I Mig92, I M I995, [2M384I, I M646, 2M607, I Mi679, 2M2035, I M2373, I MII40 and IMI843]; and group 2 comprises Ib plasmids IMII68 and IMI420. Those whose inclusion is uncertain because they show unstable coexistence with another member of the same group are in brackets.

The relationship between these two groups and those recently described (Hedges \& Datta, I973) for R factors that determine I pili and the Coll plasmids Ia-CA53 and Ib-P9 has not been tested. It seems likely, however, that our group I corresponds to their group I $\alpha$ since Ia-CA53 and Ib-P9 are common to both.

This work was supported by a grant from the Medical Research Council of New Zealand.

\section{REFERENCES}

Datta, N. \& Hedges, R. W. (1973). R factors of compatibility group A. Journal of General Microbiology 74, $335-336$.

Dowman, J. E. \& Meynell, G. G. (1970). Pleiotropic effects of derepressed bacterial sex factors on colicinogeny and cell wall structure. Molecular and General Genetics 109, 57-68.

Grindley, N. D. E., Grindley, J. N. \& Anderson, E. S. (1972). R factor compatibility groups. Molecular and General Genetics 119, 287-297.

Hedges, R. W. \& Datta, N. ( 1973 ). Plasmids determining I pili constitute a compatibility complex. Journal of General Microbiology 77, 19-25.

Howarth-Thompson, S. (1966). Influence of various coll factors on the lethal and mutagenic effects of ultraviolet radiation. Proceedings of the University of Otago Medical School 44, 5-7.

Howarth-Thompson, S., Meikle, J. D. \& CAve, A. L. (197I). Variation in properties of wild coll factors. Proceedings of the University of Otago Medical School 49, 3I-32.

Lawn, A. M., Meynell, E., Meynell, G. G. \& Datta, N. (1967). Sex pili and the classification of sex factors in the Enterobacteriaceae. Nature, London 216, 343-346.

Novick, R. P. (1969). Extrachromosomal inheritance in bacteria. Bacteriological Reviews 33, 210-235.

Ozeki, H., Stocker, B. A. D. \& Smith, S. M. (1962). Transmission of colicinogeny between strains of Salmonella typhimurium grown together. Journal of General Microbiology 28, $67 \mathrm{I}-687$.

Stocker, B. A. D. (I966). Heterogeneity of I colicines and I colicine factors. Heredity 21, 166.

Stocker, B. A. D., Sмiтh, S. M. \& OZeKI, H. (1963). High infectivity of Salmonella typhimuritum newly infected by the coll factor. Journal of General Microbiology 30, 20I-22I. 